for world peace. In that year Cannon remarked that the outcome of the efforts, which were being encouraged by the Soviet Government, to use Pavlov's methods to condition the cortex in new ways and thereby to bring about a reformation of conduct would be watched with supreme interest? Pavlov himself, in a letter to young scientific workers shortly before his death, said: "It is a matter of honour for the youth, as well as for all of us, to justify those great hopes which our fatherland places in science".

Pavlov has been accused of over-simplifying a remarkably complex subject, but his theories have provided useful working hypotheses and they have stimulated effort and increased the extent of careful experiments by those who agreed as well as those who disagreed with his views. He himself considered theories as worth while only for finding new lines of attack and accumulating facts. He stressed the importance of repeated tests to establish the reproducibility of results, and he shrank from making general conclusions. His work affords a striking example of true scientific method, and it is satisfactory to learn that his colleagues in the U.S.S.R. have been able to develop it still further in spite of the difficulties of war conditions.

${ }^{1}$ Frolov, "Pavlov and His School" (London: Kegan Paul, Trench, Trubner and Co., Ltd., 1937).

2 Proc. Roy. Soc. Edin., 56, 264 (1935-36).

- Pavlov, "The Work of the Digestive Glands", translated by W. H. Thompson (London: Charles Griffin and Co., 1902).

-Anrep, Royal Society Obituary Notices, 2 (1936).

- Pavlov, "Conditioned Reflexes" (Oxford : Univ. Press, 1927).

- "Lectures on Conditioned Reflexes", Pavlov. Vol. 2, translated and

edited by W. Horsley Gantt (International Publishers, 1941). Sce also Vol, 1.

"Cannon, W. B., "Ivan P. Pavlov", Res. Bull. Sov, Union (1935).

\section{THE ROYAL NAVAL SCIENTIFIC SERVICE}

$\mathrm{D}^{\mathrm{u}}$ URING the War of 1914-18 technical progress went ahead, as has again happened in this War, at a vastly increased rate in all the Services. In order to compete with the demands for new weapons and counter-measures, the help of numbers of men of science from the universities and technical men from private firms was enlisted, and these men were employed in naval establishments all over Great Britain. They were employed very largely on new methods for detecting and destroying enemy submarines and on developments in radio, new types of mines, methods of mine-sweeping, work on underwater explosions, torpedoes and navigational devices and the like. The work of these men was of immeasurable value to the Navy, and directly after the War the Admiralty decided, as a result of its experiences during the War, to set up a civilian scientific research department under a civilian Director of Scientific Research. The first Director of Scientific Research in the Admiralty was appointed at the beginning of 1919. He was Sir Frank Smith, who had himself during the War been largely eoncerned with the development of a type of magnetic mine which can be regarded as a forerunner of the German magnetic mine, which was used against Britain during this War. The Admiralty also set up its own research laboratory under the Director of Scientific Research for the conduct of the more fundamental types of scientific investigation.

Gradually during the years of peace the civilian scientific and technical staffs employed in the Naval
Establishments were put under the general adminis. trative control of the Director of Scientific Research, instead of being separately administered as they had been during the War. These staffs were embodied in the Admiralty Scientific, Technical and Chemical Pools, and this arrangement ensured a greater measure of uniformity in the conditions of service in the different establishments, and among people engaged on different types of research and development work, and it also ensured common methods of selection and entry into the scientific, technical and chemical services of the Admiralty. During the years of peace also, the Air Ministry and War Office set up civilian scientific research departments, which were modelled very largely on the Admiralty organization.

The steps outlined above were steps in the right direction, but there is no doubt that the Navy, and indeed the other Services, suffered a good deal because the conditions of service of the civilian technical staffs were not such as could attract the best types of men from the universities and other sources upon which the Admiralty depended. Apart from pay and promotion prospects, the lack of opportunity for publication and loss of outside recognition, as well as rather rigid research programmes, were against the Services in their need for first-rate men.

Some of the men of science and engineers who entered the Admiralty Service in the War of 1914-18 are still there, and it is to the work of these men and to those who entered the Service during the years of peace that we owe our state of preparedness, such as it was, to meet the onslaught of Germany. During the present War, the permanent Admiralty staffs have again been greatly strengthened in numbers and in quality by men of science and engineers drawn again from the universities, research institutions, private firms and other sources. The great advances which have been made in almost every form of technical weapon and in counter-measures are largely due to this body of people, working in the closest daily association with industry and outside men of science and engineers, including those of the United States and the Dominions, with the naval technical departments, and with the divisions of the naval staff, who decide in broad outline what are the Service needs.

The announcement of the formation of the Royal Naval Scientific Service is an indication that the Admiralty, having been the first Service department to take the then epoch-making step of setting up a civilian research department within its organization, still recognizes the vital importance of taking yet further steps to ensure that scientific research and technical development for the Navy shall not lag behind during the future years of peace.

The Admiralty desires to see the closest co-operation between the men of science and the uniformed officers of the Service, and it proposes giving fuller opportunities than have hitherto been regularly possible for civilians to become thoroughly versed in the ways and the needs of the Service. Further, the civilians will, by virtue of the arrangements which will be made for obtaining sea training and experience, come to feel that they are more than ever before an integral part of the Navy. The Fleet Order shows also that the Director of Scientific Research, as head of the Royal Naval Scientific Service, will have greater freedom than hitherto in arranging for transfers of staff between establishments, so that the outlook of the technical men will become broader and more enlightened than it is apt to be if men of science and engineers specialize too long or too early in 
particular aspects of Naval warfare. The reference to conditions of service including pay and prospects of promotion is vague, but it must be accepted at present as an earnest of the good intentions of the Admiralty.

The Admiralty and Government policy towards research in post-war years aims at giving research and research workers-in the broadest senserecognition and status which they have hitherto lacked in Great Britain. It is also hoped that the R.N.S.S. will be accounted an honourable career for men whose leanings are towards science and the sea; that prospects offered by the R.N.S.S. will attract men of the highest calibre to devote their minds and their lives to solving the great problems which lie ahead of the Navy; that, though the Government service cannot generally offer monetary rewards comparable with those of the highest walks of industry, yet the other advantages of a Naval technical career will offset the possible financial disadvantage ; that the Admiralty will be enabled to keep after the War some of the brilliant men who are serving it temporarily now; that there will be greater freedom for individual research workers to follow up lines of investigation for which they are personally fitted, and that the Government will not be so much inclined to look for quick returns.

\section{OBITUARIES}

\section{Sir Arthur Smith Woodward, F.R.S.}

Sir ARThur Smith Woodward, lately keeper of the Department of Geology, British Museum (Natural History), died on September 2 at the age of eighty.

Sir Arthur was a great student of vertebrate palæontology, the widest in his work and knowledge of his time. When he left Owens College, Manchester, as a very young man to take a post in the Museum, he recognized that the work of $R$. H. Traquair on palæozoic fish had introduced a new standard of investigation and a new outlook, and immediately applied them to the study of later fishes. He travelled extensively so that he saw nearly all the original materials in the world, and his extraordinary memory enabled him to recall immediately anything which could throw light on the fossils on which he was actually working. Thus his catalogue of the fossil fishes in the British Museum marks an epoch in the study of such things. It was the first completely general detailed work since Agassiz's "Poissons Fossiles" and it has had no successor, so that it remains the point of departure from which all subsequent work has proceeded. To him came collections of fossil fish from every part of the world, to be in turn described, placed in their position in the classification, and their geological horizon determined. Thus he became known to palæontologists everywhere, and was ultimately a foreign member of some twenty scientific societies.

But Sir Arthur's interests extended far beyond fish. He wrote on fossil Amphibia, reptiles, birds and mammals, doing something of interest in each of those groups, and finally he described the Piltdown man, actually himself finding part of the material at Piltdown.

His quality was well illustrated by the text-book of vertebrate palæontology which he published in 1900. This differed in every way from those which then existed; it was accurate, it dealt only with forms which were important morphologically, it was based entirely on materials which the author had seen, and it was readable.

When Sir Arthur entered the Museum the collections of fossil vertebrates, though large, had not been brought together on any considered plan. Under his influence and guidance they were expanded so that every important fauna in the world was represented, often by most admirable materials. But all were bought, sometimes after they had been sought for many years. Although Smith Woodward himself made a collection of fossil mammals at Pikermi, and Andrews explored the Fayum, no expedition was ever sent out at Museum expense; in consequence, during the past thirty years many foreign museums have exploited fossil faunas which are now inadequately or not at all represented in London.

But Smith Woodward always felt that he was a public servant. Everyone, British or foreign, had access to all the fossils in his charge, and was allowed to describe anything he wished. Thus the Museum gained because its collections were worked over by men from many countries, and palæontology gained because specialists could use its materials, as if they belonged to their own institutions.

So Smith Woodward became known and admired by the whole body of palæontologists, occupying a place no one can now fill, and leaving behind a great mass of admirable work, part of the foundation of modern palæontology.

D. M. S. WATSON.

\section{Prof. S. P. Mercer, O.B.E.}

Through the death of Prof. Stephen Pascal Mercer which occurred on August 18 at the comparatively early age of fifty-three, Northern Ireland has lost an outstanding figure in the field of agricultural educa. tion and one who played a prominent part in laying a sound foundation for the Faculty of Agriculture of Queen's University, Belfast.

S. P. Mercer (S.P.M., as he was known to so many of us) was a Staffordshire man-- the son of Mr. Fred Mercer, the landscape painter-and was born at Abbots Bromley in 1891. His leaning towards the study of agricultural science became apparent at an early age and is confirmed by his career as a student at Harper Adams, the Botanisches Staatsinstitut, Hamburg, and the South-Eastern Agricultural College. He was a graduate in agriculture of the University of London, and held the National Diploma in Agriculture. Before coming to Northern Ireland, Prof. Mercer held appointments as lecturer in charge of the Department of Agricultural Botany at Armstrong College, adviser in agricultural botany for the northern counties of England, and divisional organizer for the Northern Province under the Food Production Department of the Ministry of Agriculture and Fisheries. During 1919-22 he was assistant director and chief research officer in the Seed Testing Station for England and Wales. It was while holding this appointment that he made his survey of seed growing in Great Britain, which is the best known of his earlier work.

On his appointment, in 1922, as head of the Seed Testing and Plant Disease Division of the Ministry of Agriculture for Northern Ireland, he threw himself energetically into the organization of the Northern Ireland Seed Testing Station, where his long experience 